\title{
175 Years of Chemistry at the University of Zurich: Tradition, Dedication and Vision
}

\author{
Jay S. Siegel*
}

\begin{abstract}
April 29th, 2008 marks 175 years that chemistry has thrived as a leading discipline at the University of Zurich and in the intellectual life of Zurich. This issue of CHIMIA is dedicated to honoring this venerable history and celebrating the exciting present-day activities that point to positive future developments for chemistry in Zurich.
\end{abstract}

Keywords: Chemistry Institutes UZH · History of chemistry

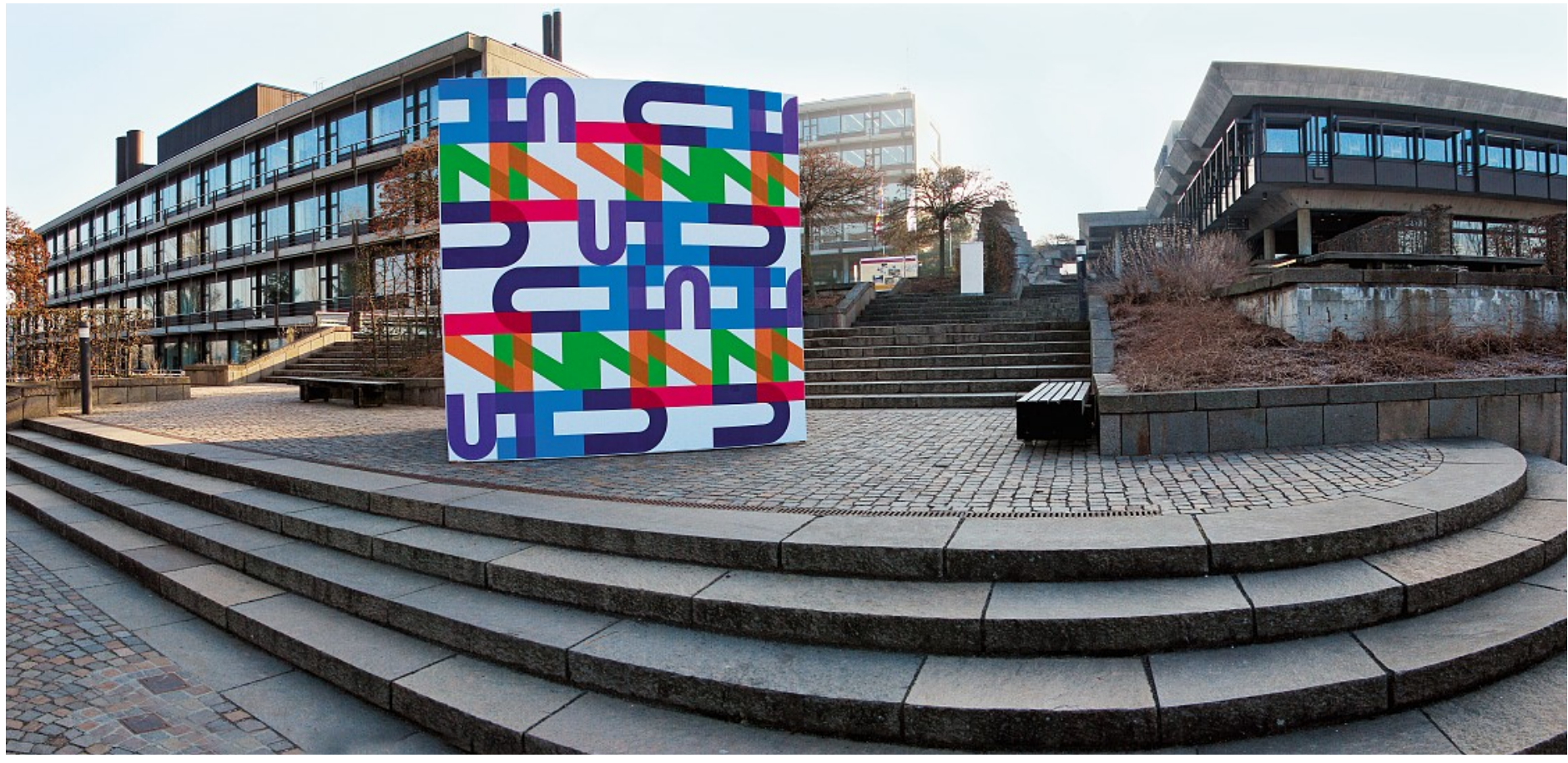

${ }^{*}$ Correspondence: Prof. Dr. J. S. Siegel Institute of Organic Chemistry

University of Zurich

Winterthurerstrasse 190

$\mathrm{CH}-8006$ Zurich

Tel.: +41446354281

Fax: +41446356888

E-mail: jss@oci.uzh.ch

\section{Introduction}

April 29th, 2008 marks 175 years that chemistry has thrived as a leading discipline at UZH and in the intellectual life of Zurich. This issue of CHIMIA is dedicated to honoring this venerable history and celebrating the exciting present-day activities that point to positive future developments for chemistry in Zurich.

The motto of UZH 175th anniversary is Wissen Teilen (Sharing Knowledge) to which a corollary would be - Wissen schaffen durch Wissen teilen - (Sharing Knowledge by Seeking Knowledge). This embodies the idea that a balanced university chemistry program displays a dedica- tion to more than advancements in research of new knowledge; it promotes innovation in the teaching and the fostering of young minds, providing creative leadership and force for progressive change in our academic and social community.

The special role of chemistry as the science of all things material, links the advances of chemical research to art, science and technology. Chemical research blends the artisan's craft with the philosopher's dilemma, and as such spans the breadth of scholarly activities from pure philosophy to applied engineering sciences. Chemistry is a crucial part of any well-educated citizen's schooling, and an essential component of any prosperous nation's industrial technol- 
ogy. Switzerland as a nation and Zurich as a Canton, have reaped demonstrable economic and intellectual benefits from their strong chemical heritage, and the investment in the future of Chemistry remains a clever strategy for a society dependent upon innovation in medicine, materials and manufacturing.

Today, with two of Europe's strongest academic institutions only a stone's throw apart, Zurich remains a thriving hub for molecular science and related bio/nano technologies. The present standing follows from a tradition in research, dedication to teaching, and vision toward the future.

Excitement over the exploration of the molecular world combined with the socially responsive reportage of one's findings has earmarked the legions of scholars at UZH who have earned their wings as Chemists. During this period, they have forged strong personal ties to mentors and built lifelong networks that support them throughout their professional lives. This band of alumini (and of course alumnae) came from all over the globe to Zurich and now represents the UZH tradition as leaders of industry and academia worldwide. Their contribution to the UZH experience provides a strong history upon which current students can build.

Chemistry in Zurich has molded cultural, political and economic aspects of society. The discipline is wed to the Swiss (Zurcher) way of life. One could even ponder the abbreviation for Switzerland $(\mathrm{CH})$ as coming more from Chemistry than from Confoederatio Helvetica.

\section{Chemistry in Canton Zurich}

In 1833, a new university formally opened in Zurich, a city with centuries of scholarly ecumenical activity as well as extensive recognition for medicinal studies. The founders, such as Orelli, had the vision that this University should be for all of Switzerland, and should have an international reputation as a leading house for liberal thought.

The first Rector, a Physician and Natural Philosopher by background, was dedicated to an academic program founded in the research and development of new knowledge. Chemistry, with its fundamental mission to create new forms of matter and control their transformations, featured prominently in this plan. The importance of chemistry was highlighted with a charter chaired full professor and the recognition that the pursuit of chemistry meant a commitment to the technologies of its investigation.

It is well known that the soil for 19th century chemistry was extremely fertile and led propitiously to some of Switzerland's earliest Nobel Prize winners ( $c f$.
Werner and Karrer). As scholarly as that program was, it was equally clear that the many facets and broad reaching implications of chemistry could not be covered in one institution. When the Polytechnikum, now known as the ETH, was established in 1856 , the complementarity of the two institutions raised Zurich higher in the international scales than either institution could claim alone. The independent missions of these two institutions enabled each to grow strong through cooperative competition. The university with a stronger emphasis on fundamental research and a liberal pedagogical program is associated with many revolutionary changes in the conception of chemistry. Paul Karrer expressed this same sentiment $c a$. 50 years ago. I paraphrase his words here:

Numerous fundamental developments in chemistry are associated with Zurich. The high standard of chemical science pursued by Zurich's two academic institutions is responsible to a significant extent for the advance of chemistry at its roots and for the support of a strong and vibrant Swiss industry. Few cities can boast such accomplishments.

Indeed, rare are the cities of the world that can boast two leading academic institutions, which together provide the citizenry with an intellectual environment so conducive to the pursuit of enterprise and to the personal development of its future generations. Modern chemistry, as it is pursued in greater Zurich environment, continues this tradition.

Conrad Hans Eugster published a detailed history of the first 150 years of UZH chemical heritage in German 25 years ago. In this issue, Gillian Harvey has produced a translation of this work into English. Starting from this as a basis for the historical record, special focus articles highlight the individual institutes of chemistry: 75 years of Physical Chemistry by Professor Robert Huber, the Werner tradition in Inorganic Chemistry by Professor Heinz Berke and colleagues, and the last 25 years in Organic Chemistry by Professor Heinz Heimgartner and me.

Another important part of the UZH chemical legacy is the collection of research samples preserved from the researcher programs of Werner, Karrer, Schmid and Eugster. Nathaniel Finney provides a perspective on these collections in an article that traces the chemical history of UZH through these research collections.

\section{An International Program for Chemical Research}

The student composition at UZH should also reflect its international position of stature as a major hub for chemical research.
So it has been since the early days. The groups of Werner and Karrer were always large and broadly representative of the nations of the world.

One poignant example of Zurich's early international standing and synergistic interactions between UZH and ETH comes from three Japanese scientists who studied with Willstätter and Werner during the year 1910. Yuji Shibata, Rikou Majima, and Yasuhiko Asahina all completed postdoctoral stays in Zurich in 1910, and returned to Japan to found the fields of modern coordination chemistry, pharmaceutical chemistry and organic chemistry, respectively. The accomplishments of these three men in altering the face of modern chemistry in Japan are amply documented in historical works, all of which cite their respective times in Zurich. That they knew each other and socialized collectively during their $\mathrm{Zu}$ rich days is documented in a now famous tourist photo (Fig. 1). Three such influential figures, two leading chemical research centers, one great city!

The latter groups, such as Schwarzenbach, Schmid and Clusius, also benefited greatly from an international mix of students. Indeed the university, from conception to today, boasts of a cosmopolitan working environment.

Local and international 'Nachwuchs', or youth development, was an early forte of the Zurich school, and was driven by the vision of the patriarchs. In addition to the Japanese anecdote above, numerous chemistry professors and industry leaders came from the labs on Rämistrasse.

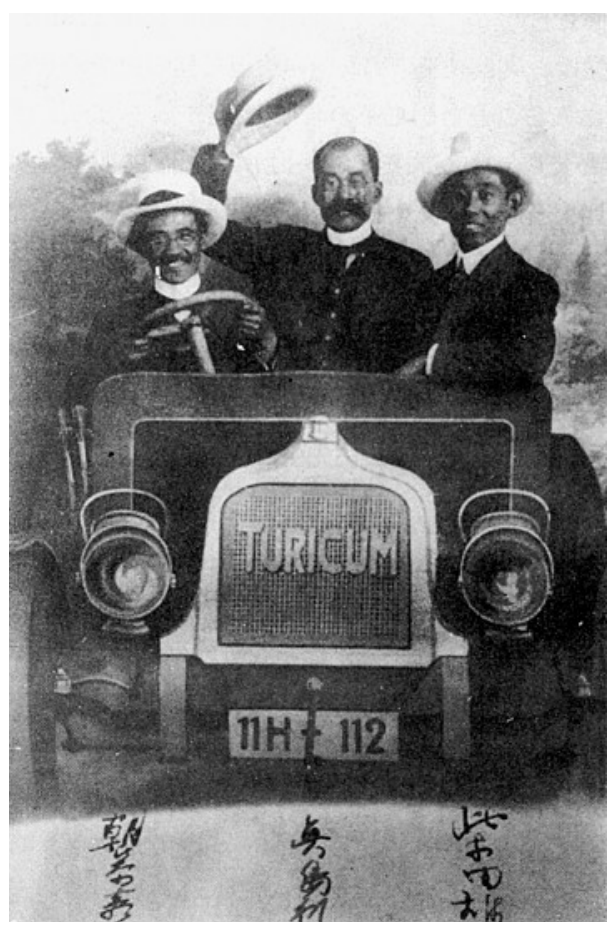

Fig. 1. Yuji Shibata, Rikou Majima and Yasuhiko Asahina sharing a social day in Zurich during their postdoctoral studies in 1910 
With Bologna reforms in curricula, mobility among universities of different countries should become easier and the student body should become even more international. A liberalization of the curriculum to afford students a chance to pursue more interdisciplinary areas is greatly anticipated. The international flavor is highly prized at $\mathrm{UZH}$, and our program continues to evolve to accommodate students from all science study backgrounds into chemistry.

As with all present day global ventures, the use of English as a lingua franca greatly facilitates intercultural exchange, and in this spirit teaching in Chemistry at UZH prepares students for a global career. Mixed international character, English discussion, and a liberal curriculum, make UZH a progressive chemical research environment.

The international tradition of UZH has grown with time. Today the student and professorial ranks are broadly populated with the best scientists from Europe, Asia and the Americas. Chemistry at UZH is thus best seen as an international program in the service of Canton Zurich.

Within the 'Fachbereich' for Chemistry and Biochemistry, a new joint venture has developed in the form of the Graduate School for Chemical and Molecular Sciences, Zurich (CMSZH). Dr. Ferdinand Wild and Professor Roland Sigel provide an outline of the new program, its requirements, benefits and motivations. Such cooperative programs throughout the faculty of math and natural science provide strong networks for research students to obtain broad training, while staying on the cuttingedge of research in chemistry.

\section{Dedication to Teaching}

Not only is chemistry at UZH one of the oldest formally structured disciplines, but it has also been a focus point for teaching and curricular development. The university forefathers understood the importance of chemistry and established a chair for chemistry among the inaugural professorships. The pedagogical prowess of the first Professor of Chemistry, Carl Jakob Löwig, was known locally for his elegant lecture style and internationally for his acclaimed textbook on general chemistry. The importance placed on practical work as part of the education was strong, and systematic methods in the laboratory were paramount, as illustrated in Städeler's handbook for the systematic qualitative analysis of chemical species.

Werner, in 1904, made major advances in the teaching of stereochemistry through his book on the topic, and in the same year, he revolutionized chemical research and education by effectively creating and structuring the field of inorganic chemistry in one

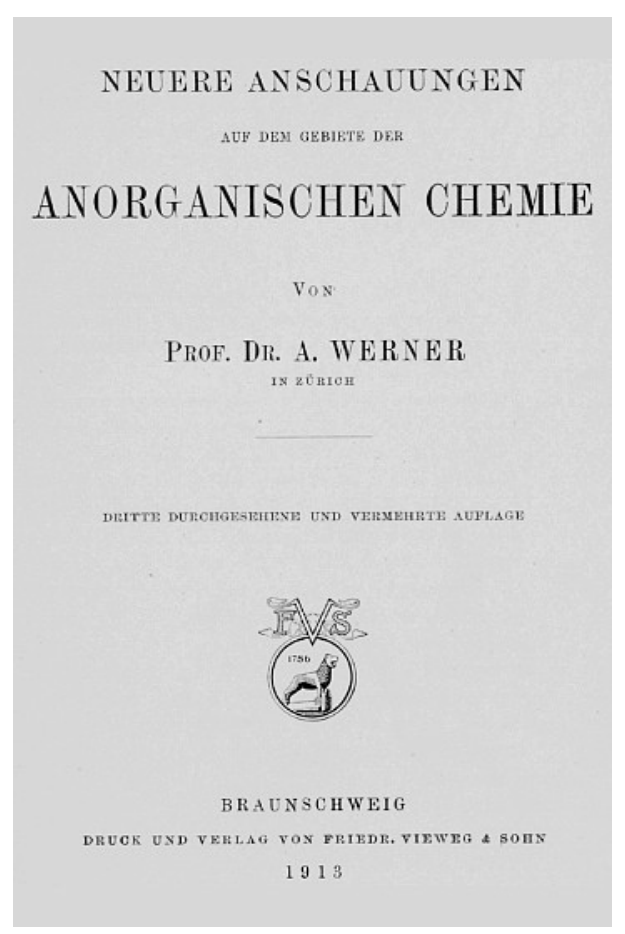

Fig. 2. Werner's text

groundbreaking text (Fig. 2). This text has recently received an award from the History of Chemistry Division of the American Chemical Society as a most influential text in the development of chemistry.

Karrer wrote a text on Organic chemistry that was internationally renowned as the 'Karrer's Bible' (Fig. 3). The book carried through 13 editions and was translated into numerous international languages, including Russian and Japanese. Professor Emeritus André Dreiding fondly recalls his time as a student at Columbia University in New York. He notes that, at that time, Karrer's text was considered the authoritative text. Karrer structured his book based on functional groups and substance classes. The book included many experimental details, and a selection of appendices with valuable empirical data.

Schwarzenbach's text on General and Inorganic Chemistry set a new level in presenting a broad vision and underlying principles of chemistry to the introductory student. This tradition in providing pedagogically sound textbooks has continued (see Table 1).

As well, practical training at UZH has been at the forefront of instruction, conceptually and technologically. Laboratory training for students dates back to the beginning of $\mathrm{UZH}$, and has led the way forward with numerous innovations over the years. Today, it is fashionable to speak of green chemistry and sustainability, but already in the 1990s the Zurich Model was well known as an efficient structure for a laboratory class oriented toward protecting the environment and reducing waste, while still providing substantial training. ${ }^{[1]}$ In 1994, Fischer and Eugster published through VHCA a labora-

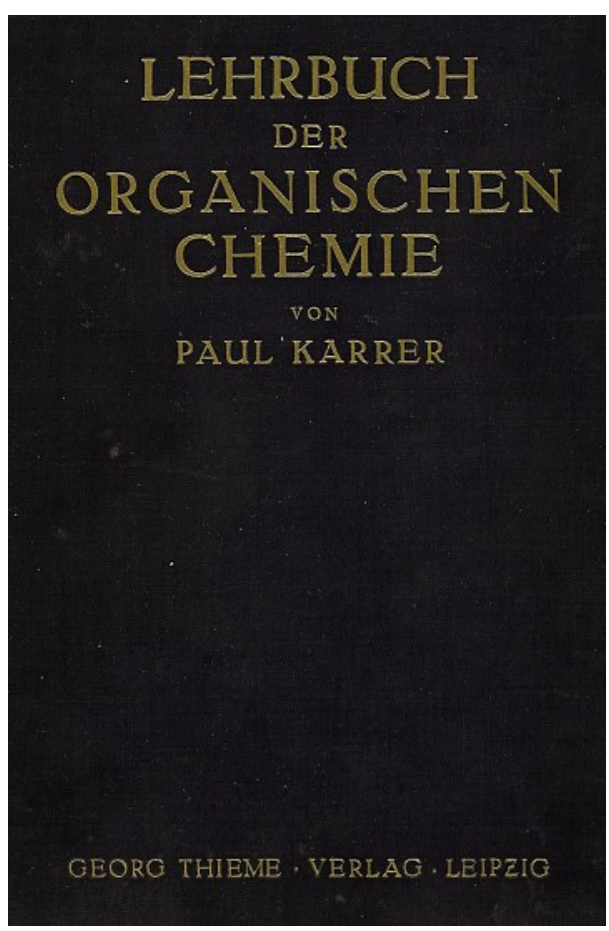

Fig. 3. Karrer's text

tory manual that covered the broad aspects of practical chemistry in two volumes.

New modern day advances in the practical laboratory include plans to meld Organic, Inorganic and Physical laboratories into a unified comprehensive training/research lab experience. The addition of automation for process development and optimization in upper division practical work, harmonize well with our Academic/Industry joint venture, the Laboratorium für Prozessforschung ( $L P F)$.

The modern concept of chemistry certainly could not be taught without the aid provided by reliable molecular models. No matter the quality of new computer simulations, chemists and common folk still have a fascination for hand-held models. Here too UZH was at the forefront. An exceptional set of models were developed by André Dreiding. Every student of conformational analysis has benefited enormously from 'Dreiding Models' (Fig. 4).

This tradition in the development of new curricula continually energizes us to consider our discipline more broadly and more deeply. The recent establishment of a bachelor's and master's program in Business Chemistry (Wirtschaftschemie) at UZH marks the first such program in Switzerland, and has led to an increased interest and number of entering students to chemistry study. Professor Stefan Seeger, the founder of the Business Chemistry program at UZH, depicts this full-fledged chemistry course of study in his article.

Additional changes in the program will no doubt continue to lead the way in evolving how the chemical course of study is conceived. As more and more of chemical 
Table 1. Selected historical textbooks from the Chemistry Institutes UZH

\begin{tabular}{|c|c|c|c|}
\hline Professor & Title & Year & Publisher \\
\hline & Theory (Lecture) Textbooks & & \\
\hline \multirow[t]{2}{*}{ Karl J Löwig } & $\begin{array}{l}\text { Lehrbuch der Chemie: mit besonderer Berück- } \\
\text { sichtigung des technischen und medizinischen } \\
\text { Theils. }\end{array}$ & 1832 & $\begin{array}{l}\text { Engelmann, } \\
\text { Heidelberg }\end{array}$ \\
\hline & $\begin{array}{l}\text { Chemie der organischen Verbindungen } \\
\text { ( } 2 \text { editions) }\end{array}$ & $\begin{array}{l}1838 \\
1947\end{array}$ & Vieweg, Braunschweig \\
\hline \multirow[t]{2}{*}{ Alfred Werner } & $\begin{array}{l}\text { Neuere Anschauungen auf dem Gebiete der } \\
\text { anorganischen Chemie }\end{array}$ & 1904 & $\begin{array}{l}\text { Vieweg \& Sohn, } \\
\text { Braunschweig }\end{array}$ \\
\hline & Lehrbuch der Stereochemie & 1904 & Gustav Fischer, Jena \\
\hline Paul Karrer & $\begin{array}{l}\text { Lehrbuch der organischen Chemie } \\
\text { (14 editions) }\end{array}$ & 1927 & Thieme, Stuttgart \\
\hline \multirow[t]{2}{*}{ Karl W Nägeli } & Lehrbuch der Chemie für Mediziner & 1935 & Thieme, Stuttgart \\
\hline & $\begin{array}{l}\text { Oppenheimer's Grundriss der organischen Che- } \\
\text { mie. } 15 \text { th edition }\end{array}$ & 1938 & Thieme, Stuttgart \\
\hline $\begin{array}{l}\text { Gerold } \\
\text { Schwarzenbach }\end{array}$ & $\begin{array}{l}\text { Allgemeine und anorganische Chemie: ein ein- } \\
\text { faches Lehrbuch auf neuzeitlicher Grundlage }\end{array}$ & 1941 & Thieme, Stuttgart \\
\hline H. Labhart, & Einführung in die Physikalische Chemie & 1975 & $\begin{array}{l}\text { Springer-Verlag. } \\
\text { Berlin }\end{array}$ \\
\hline \multirow[t]{2}{*}{ Georges Wagniere } & $\begin{array}{l}\text { Introduction to Elementary Molecular Orbital } \\
\text { Theory and to Semiempirical Methods }\end{array}$ & 1976 & $\begin{array}{l}\text { Springer-Verlag, } \\
\text { Berlin }\end{array}$ \\
\hline & Practical Textbooks & & \\
\hline Georg A K Städeler & $\begin{array}{l}\text { Leitfaden für die qualitative chemische Analyse } \\
\text { unorganischer Körper ( } 3 \text { editions) }\end{array}$ & 1861 & Orell Füssli, Zürich \\
\hline $\begin{array}{l}\text { Manfred Hesse, } \\
\text { Herbert Meier, } \\
\text { Bernd Zeeh }\end{array}$ & $\begin{array}{l}\text { Spektroskopische Methoden in der organischen } \\
\text { Chemie } \\
\text { 7. Auflage } 2005\end{array}$ & 1995 & Thieme, Stuttgart \\
\hline $\begin{array}{l}\text { Hans Fischer, } \\
\text { Conrad Eugster }\end{array}$ & $\begin{array}{l}\text { Praktikum in Allgemeiner Chemie (Ein umwelt- } \\
\text { schonendes Programm für Studienanfänger mit } \\
\text { Versuchen zur Chemikalien- Rückgewinnung), } \\
\text { Teil I, Allgemeine und Anorganische Chemie, } \\
\text { Teil II, Organische und Physikalische Chemie. }\end{array}$ & $1994 / 95$ & VCHA-VCH \\
\hline
\end{tabular}

hypotheses are founded on the basis of our ability to control material structure at the molecular level, a move toward teaching the skills underpinning the design, synthesis and analysis of molecules as a collective and synergistic activity will become more prominent. Molecular design and synthesis could well serve as a theme that unites research and teaching in the molecular sciences.

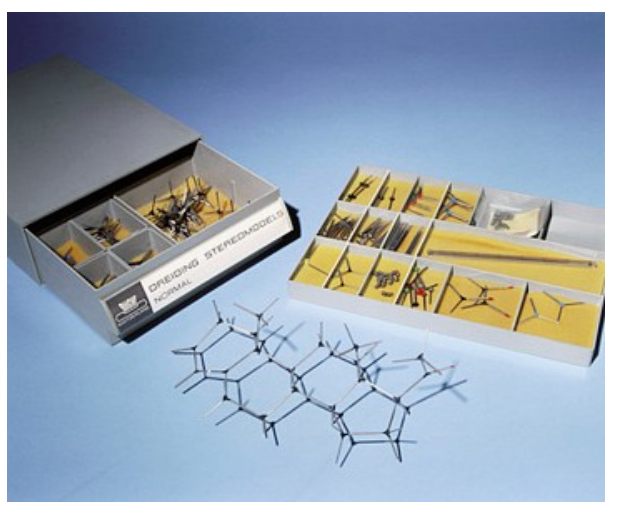

Fig. 4. Dreiding models

\section{Alumni - An Important Extended Chemical Family}

No surprise that after 175 years a large number of undergraduate and doctoral students, as well as post-doctoral and habilitation researchers, have contributed to and benefited from the chemistry program at UZH. Some, like Professor Yuji Shibata (mentioned above), come from far lands and subsequently return home to revolutionize chemistry in their home country. Others are born only a stone's throw from the chemical laboratories, perhaps at the Unispital, and they remain in Zurich teaching and mentoring the next generation. No matter their background or career path, they received a fundamental formation of their intellectual character through study and research at UZH.

One of our most revolutionary alumni is the centenarian Dr. Albert Hofmann (Fig. 5). He revolutionized the world with his discovery of LSD and his realization that there could be entire families of chemical species that act selectively on the human conscience. At 102, he still remembers with great sentiment his time at $\mathrm{UZH}$ as a doctoral student with Karrer. His training on the systematic approach to the isolation and characterization of natural products, learned during his UZH experience, guided him to be a meticulous professional medicinal chemist. Through this act of becoming a 'prepared mind', he prepared himself to realize the nature and importance of his chance discovery.

Training in how to approach problems from a chemical/molecular perspective prepares one for a variety of career paths. Another more recent alumnus, Dr. Volkan Kísakürek, became the principal editor of Verlag Helvetica Chimica Acta, which is responsible for publishing an enormous number of books and research articles reporting ground-breaking results of Swiss and other scientists. Graduates of UZH chemistry have taken on various careers in academia, industry, finance, law, etc.

As a tribute to our alumni and in celebration of the alumni tradition, several former students with close remaining ties to UZH have provided a series of personal perspectives or short profiles of their experience at $\mathrm{UZH}$ and in their latter career. Since their time at UZH, they have become Professors, Founders of Companies, Heads of Industrial Research, Patent Attorneys, among other careers. They clearly illustrate how personally beneficial a UZH training can be.

\section{A Tradition of Giving}

The support of chemistry at UZH has not been restricted to purely academic pursuits. UZH has a long history of supporting innovation and industrial entrepreneurial activity. Numerous chemists have had the opportunity to start business-oriented en-

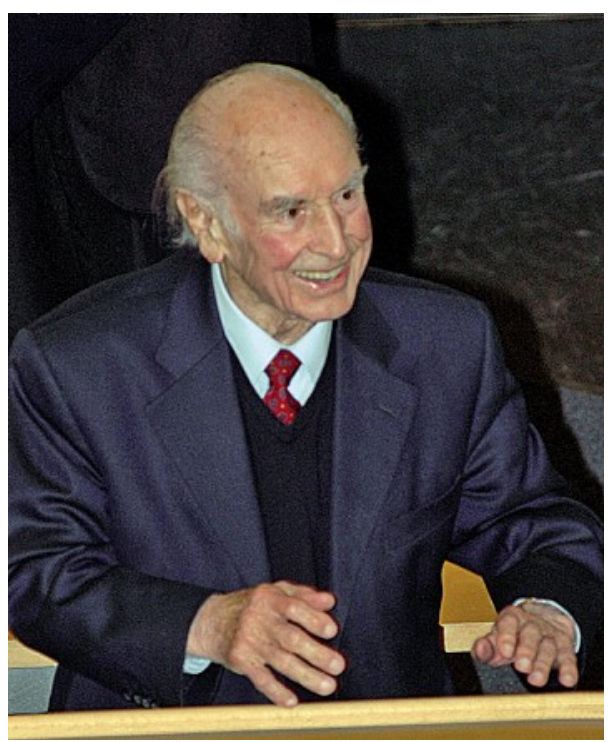

Fig. 5. Alumnus Dr. Albert Hofmann at his centennial birthday celebration in the Irchel Campus 
terprises as spin-offs or seed ventures of the University. Two of the most successful ventures led to the formation of Polyphor and Carbogen. Alumni perspectives of these two founding groups tell a bit about the fertile environment provided by UZH chemistry.

As noted in the article from Carbogen's founders, UZH's support of start-up and spin-off enterprises has had a positive influence on our broader vision of personal development offerings in chemistry. In 2003, after the untimely death of LPF Director, Max Rey, UZH took over control of the LPF and developed the labs into an institute dedicated to the training of postdoctoral researchers in process chemistry. In this short history, the LPF has trained and placed in professional career positions over 20 postdoctoral chemists. Companies such as Cilag, Siegfried, Lonza, Fluka (SAFC), EMS-Dottikon, among others, now benefit from chemists trained at the new LPF.

As of 2007, UZH has revitalized the apprentice program in chemistry through the appointment of a dedicated 'Lehrmeister' in charge of a fully outfitted 'Lehrlabor'. The program already has enlisted six young chemistry apprentices. Together with ETHZ and Givaudan, the UZH program becomes one of the cornerstone programs for a broad chemistry apprenticeship with synthetic and analytic expert training. The goal is to grow the program to an equilibrium enrollment of close to 20 young chemists (ages 16-20).

Consideration of the 'Kinder' and 'Senioren' lecture programs and numerous public lecture series in addition to the normal curriculum and special programs like the apprentice study and LPF internships, UZH strives to provide to the citizens of Canton Zurich personal development opportunities for all ages and educational levels. For 175 years, takes pride in being Canton Zurich's major educational opportunity provider.

Appreciation from the faculty students, and community, for the rich intellectual climate of the Chemical Institutes, has been strong over the years. Already back around the turn of last century, alumni, emeriti and concerned community members have found personal satisfaction from donating time and finances to support chemistry at $\mathrm{UZH}$ in recognition of a benevolent Alma mater.

The tradition of giving from chemistry's alumni and emeriti has been long and generous. Even in the 1800 s, the tradition of giving back to UZH in thanks for years of scholarly support and to foster an even better intellectual environment for future generations, was strong. Perhaps the first formal fund was established in the late 1800 s as the 'Merz Legat'. This legacy funded the acquisition of much needed research monographs related to chemistry for the library.

Since that seminal act of giving, several members of the UZH chemical family and/ or their relations have made donation to advance chemistry. Notable are the funds administered by the university, such as the Alfred Werner Legat, donated by the family of Alfred Werner, and the Betty Sassella Legat. The Werner Legat has grown into a substantial and influential fund on campus. The Legat provides research funds for acquisition of small research equipment, and recognizes accomplishments of our finest students through achievement awards. The Sassella Legat supports inter-collegial activities that enrich scholarly life.

In addition, private foundations dedicated to specific activities in the various chemical institutes, contribute. The Dr. Helmut Legerlotz-Stiftung provides postdoctoral stipends to outstanding chemists, pursuing research in Organic chemistry. The Prof. Dr. Hans E. Schmid-Stiftung was established to aid co-workers of the OCI. In memory of Professor Schmid's exemplary leadership and untimely passing, this fund now allows international students of exceptional quality to pursue Master's studies at UZH. As no formal funding mechanism exists for MS stipends, these funds make a critical difference in the lives of exceptional young scholars.

In addition to enabling individuals through stipends, the Legerlotz Stiftung provides apartments in a so-called 'Legerlotzhaus'. These accommodations allow students to find affordable housing in Zurich during their study time. Through such donations, the alumni not only give back to UZH, but also create opportunities for their academic younger cousins to enjoy the golden research experience that only an institution of the quality of UZH can provide.

The Legerlotz Stiftung also has provisions to support the purchase of major instrumentation. Key advancements to the chemistry infrastructure have been enabled over the years due to this fund. The entire chemistry community is deeply indebted to Dr. Legerlotz and his family for their exceptional generosity.

\section{Bestowing of Honors in Appreciation of Excellence}

Another area where community support has raised the stature of UZH chemistry, is through funds for awarding of international prizes in recognition of excellence in chemistry. At present, the Karrer Stiftung, Siegfried Corporation, and Albert Hofmann Centennial funds, enable us to award the internationally received, Karrer, Siegfried and Albert Hofmann Centennial Medals, respectively (Fig. 6).

The Foundation for the Paul Karrer Lecture was established in 1959 by the companies: CIBA AG, J.R. Geigy, F. Hoffmann-La Roche \& Co. AG, Sandoz AG, Société des Produits Nestlé AG and Dr. A. Wander AG. The intention of the donors was to honor contributions to the development of chemistry made by Paul Karrer. The Foundation invites, either annually or biannually, outstanding researchers in the field of chemistry to present a scientific lecture at the University of Zurich. Among the recipients are nine Nobel Prize winners for chemistry and for medicine, and they have represented nearly all important research institutions of Europe and the USA. The most recent recipient, 2007, was Professor Steve Ley of Cambridge University. Professor Ley contributes to this issue with an account of his award lecture.

The Siegfried company, in conjunction with the Institute of Organic Chemistry of
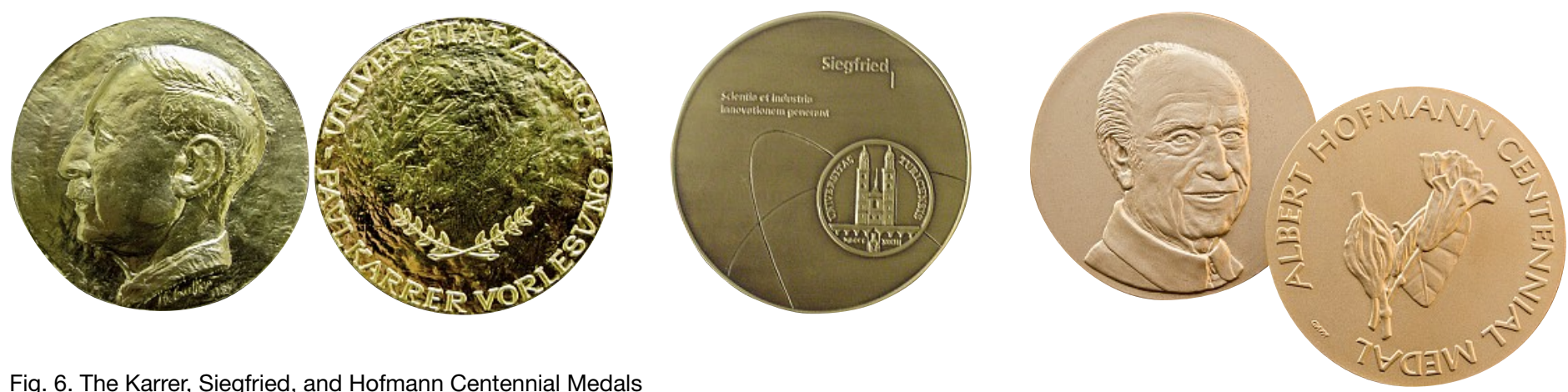

Fig. 6. The Karrer, Siegfried, and Hofmann Centennial Medals 
the University of Zurich and its Laboratory for Process Research (LPF), established the Siegfried Medal to recognize outstanding achievements and original research in chemical processes, carried out in academic and/or industrial laboratories. The award is made biennially and consists of a gold medal and an honorarium. The next Siegfried Symposium and Medal awarding is scheduled for September 4th, 2008, at the Kongresshaus in Zurich. ${ }^{[2]}$

The Hofmann Centennial celebration was established on the occasion of Albert Hofmann's 100th birthday, January 12, 2006. In 2006, UZH held a Hofmann symposium with three lectures. Dr. Hofmann, an illustrious and colorful Alumnus of UZH, attended the celebration and demonstrated his prowess in natural products chemistry even at age 100. His many advances to medicine through his investigation of natural product alkaloid chemistry, make him an appropriate symbol for a medal recognizing excellence in chemistry related to life sciences. In 2007, the Hofmann Centennial Medal was awarded to HRH Princess Chulabhorn Mahidol as inaugural recipient, for her excellence in pursuing Thailand's natural products for their important medicinal behavior.

The first Hofmann Centennial medal was awarded as part of the Dorothy Crowfoot Hodgkin Symposium (Fig. 7), founded in 2006 by Professor Kim Baldridge as an international sister event to the Maria Goeppart-Mayer Symposium, which Professor Baldridge also developed and ran for 12 years in San Diego, California. Both symposia serve to showcase the research/ scholarly achievements of great women in science. The third annual event of the $\mathrm{DCH}$ symposium will be celebrated May 9, 2008 on the Irchel Campus. This year's speakers include: Joanne Stubbe (MIT); Judith Howard (Durham); Makiko Sodeoka (Riken); and Anne Weber (Merck).

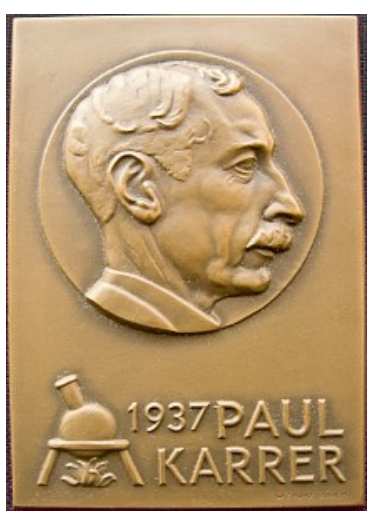

Excellence in teaching is as important as research. To celebrate Karrer's contribution to teaching organic chemistry and to honor great teacher/scholars from around the world, the OCI offers a special 'KarrerGivaudan Distinguished Visiting Professor of Organic Chemistry'. Started in 2005, already six great organic chemists have come to $\mathrm{UZH}$ to teach short special topics in organic chemistry.

\section{Leadership in the Chemical Community}

Chemists from Zurich were also key players in the establishment and leading of key scholarly societies and journals. Alfred

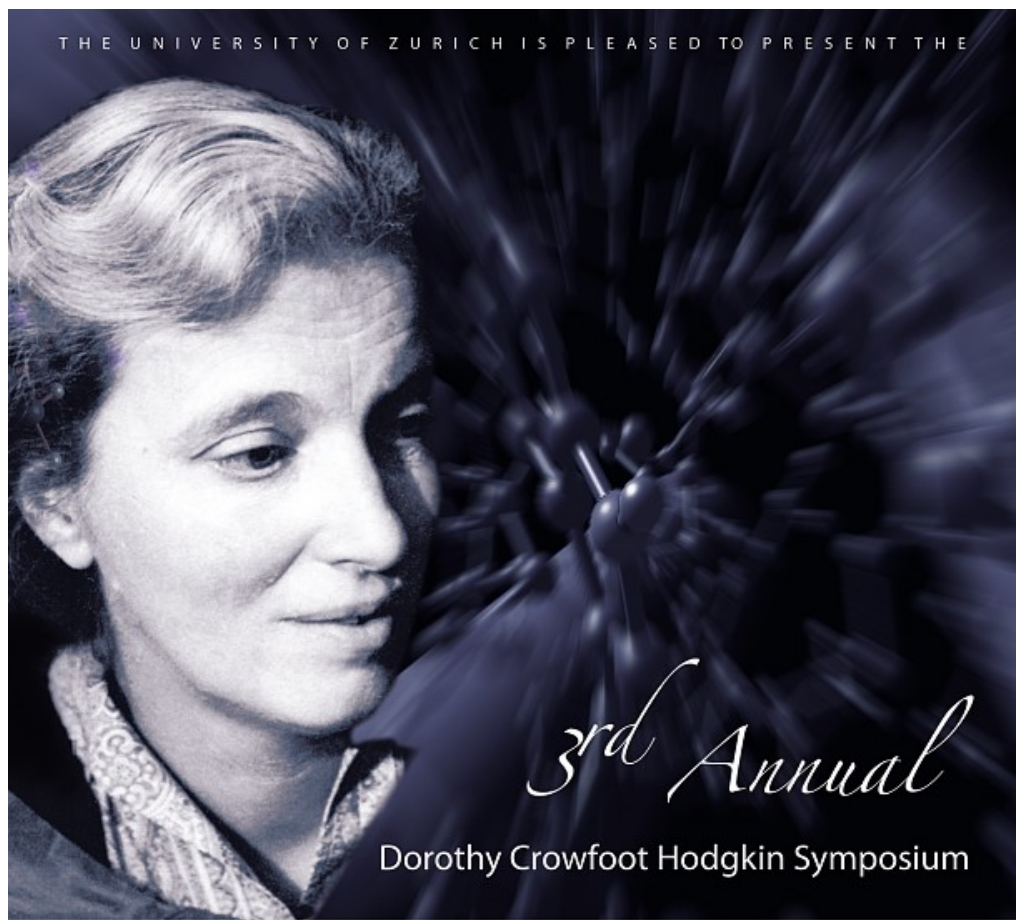

Fig. 7. Dorothy Crowfoot Hodgkin Symposium founded by Professor Baldridge in 2006

Werner was the first president of the Swiss Chemical Society and played a role in the development of Helvetica Chimica Acta as a Swiss journal of chemistry. Essentially all key chemists from UZH have over the years served the chemical society as president and or as head of the editorial board of Helvetica.

The 'Stiftung für Stipendien auf dem Gebiete der Chemie' was founded in 1944 with Paul Karrer as President. This fund provides fellowships to young researchers starting out their career in Switzerland. Initially these were habilitation stipend and now it has evolved into a six-year assistant professor fellowship.

Stimulating scientific exchange though scholarly meetings provides a special way to create a sense of community. On a grand scale, Karrer served a term as president of IUPAC and organizer of the 14th international congress. A more intimate but extremely influential conference venue is the Buergenstock conference, which is the brain child of Professor André Dreiding. The 43th Buergenstock conference will take place April 12-18, 2008.

In addition to these selected examples, today's chemists at UZH sit on the advisory or directors' boards of numerous societies, foundations, and companies. They hold key positions as editors of major peer reviewed journals and routinely organize international meetings for chemistry. Thus, the tradition of leadership in the community lives on.

\section{Laboratories and Analytical Infrastructure for Molecular Sciences}

The dedication to state-of-the-art infrastructure has enhanced chemical research over the years. Already at the time of UZH's founding, the need for laboratories and chemical apparatus/instrumentation was recognized. In 1909, the Canton of Zurich built Werner's chemical laboratory, which now houses the Law School and the renowned Calatrava Law library. In the 1970s, the vision of the Irchel campus took form, and Chemistry was among the first institutes constructed. Close to 30 years of active research later, the laboratories are well in form and function. Although specifications were set for a time well before the most modern safety and energy efficient installations, the labs were still custom designed far ahead of their time.

Advances in instrumentation play an enabling role for chemistry, and UZH has maintained a forefront position in analytical infrastructure through the development and/or acquisition of state-of-the-art instrumentation. Separations have been established in science, just as Clusius' ap- 
paratus for separation of isotopes or numerous chromatographic methods forwarded mechanistic physical chemistry as well as natural product and biosynthesis studies. Some of the first fluorescence and NMR spectral facilities enabled great advances in structural chemistry. An emphasis on mass spectroscopic technologies permitted the study of chemical components, even in trace quantities.

All of this infrastructure growth led to the development of dedicated analytical chemistry research services. Today, NMR, $\mathrm{X}$-ray crystallography, mass spectrometry, absorption/fluorescence spectroscopy, automation and computation, define a virtual Analytical Infrastructure for the Molecular Sciences (AIMS). These facilities are maintained at the highest research standard, by principal investigators with independent research programs and funding devoted to advancing the use and methods development of these techniques.

From the early years onward, UZH has invested in chemical research, and associated infrastructure and instrumentation. The building of new labs on the Rämistrasse for Werner in 1909 was a major sign of support from the Canton and the citizenry of Zurich. These labs were a model construct for their time and served in their original function until 1978, when the first phase of the Irchel campus opened with new chemical labs, again built with technologies far ahead of the times. Special energy saving and safety technologies were implemented, providing truly extraordinary laboratory facilities.

As always, now is the time to plan for the future. Within 10 years, the expectations from the community will be high for university laboratories to be 'green', environmentally sound, and equipped with infrastructure based on sustainable technologies. Such developments are possible, and would again place UZH at the forefront in academic infrastructure for the natural sciences. Given the literally billions of Swiss francs invested in highly sensitive research equipment as well as the lives and safety of the thousands of students and co-workers

Table 2. Important 2008 events in Chemistry associated with UZH

\begin{tabular}{|c|c|c|c|}
\hline Date & Event & Location & $\boldsymbol{U R} \boldsymbol{R}$ \\
\hline April 12-18 & $\begin{array}{l}\text { Bürgenstock } \\
\text { Conference }\end{array}$ & Fürigen, Nidwalden & $\begin{array}{l}\text { http://www.stereochemistry- } \\
\text { buergenstock.ch/ }\end{array}$ \\
\hline April 19 & $\begin{array}{l}\text { Faculty Day for the } \\
\text { Natural Sciences }\end{array}$ & Irchel Campus - UZH & $\begin{array}{l}\text { http://www.175jahre.uzh.ch/ } \\
\text { fakultaeten/naturwissenschaft.html }\end{array}$ \\
\hline April 20-25 & $\begin{array}{l}\text { Roald Hoffmann } \\
\text { Lectures }\end{array}$ & Irchel Campus - UZH & \\
\hline May 9 & $\begin{array}{l}\text { Dorothy Crowfoot } \\
\text { Hodgkin Symposium }\end{array}$ & Irchel Campus - UZH & $\begin{array}{l}\text { http://www.oci.uzh.ch/diversa/ } \\
\text { dch/2008/index.html }\end{array}$ \\
\hline May 14-15 & $\begin{array}{l}\text { CMSZH Graduate } \\
\text { Symposium }\end{array}$ & Irchel Campus - UZH & http://www.cmszh.uzh \\
\hline May 27 & $\begin{array}{l}\text { Georg Fràter } \\
\text { Symposium }\end{array}$ & Irchel Campus - UZH & $\begin{array}{l}\text { http://www.oci.uzh.ch/diversa/ } \\
\text { Frater/ }\end{array}$ \\
\hline June 22-July 5 & $\begin{array}{l}\text { Zurich School of } \\
\text { Crystallography }\end{array}$ & Irchel Campus - UZH & $\begin{array}{l}\text { http://www.oci.uzh.ch/diversa/ } \\
\text { xtal school/index.html }\end{array}$ \\
\hline September 4 & Siegfried Symposium & Zurich -Kongresshaus & $\begin{array}{l}\text { http://www.oci.uzh.ch/diversa/ } \\
\text { siegfriedsymposium/index.html }\end{array}$ \\
\hline September 11 & $\begin{array}{l}\text { Swiss Chemical } \\
\text { Society Fall Meeting }\end{array}$ & Irchel Campus - UZH & $\begin{array}{l}\text { http://www.swiss-chemistry.ch/ } \\
\text { events }\end{array}$ \\
\hline Fall 08 & $\begin{array}{l}\text { Albert Hoffman } \\
\text { Medal }\end{array}$ & Irchel Campus - UZH & http://www.oci.uzh.ch/diversa \\
\hline Fall 08 & $\begin{array}{l}\text { Paul Karrer } \\
\text { Medal }\end{array}$ & UZH Main Building - Aula & http://www.oci.uzh.ch/diversa \\
\hline
\end{tabular}

who daily push forward research frontiers for the benefit of Canton Zurich, it is crucial that a timely and technologically sound building development plan be set into progress early on.

\section{Chemical Changes since 2000}

The last decade has witnessed an enormous change to the chemical faculty at UZH. Roughly a dozen new professors have established research/teaching programs within this time. Particularly significant is the formal recruitment of Assistant Professors as a commitment to the development of new talent. Such new faces add a vitality and youthfulness to the program that well rounds out the more senior programs. These young scientists represent the best, chosen from a highly competitive international pool of candidates. At the current time, two have been awarded SNF professorships, and two others have received special Werner Assistant Professor Fellowships from the Foundation for Stipends in Chemistry. All come from phenomenal backgrounds and are currently pursuing cutting edge research. The dramatic increase in the enrollment beginning students certainly reflects the ability of these young scholars to convey the excitement and positive aspects of chemistry. These young prodigies carry the torch of Chemistry at the University of $\mathrm{Zu}$ rich, supported by a rich chemical tradition, a continuing dedication to research and teaching excellence, and modern vision for the evolution of the molecular sciences.

[1] H. Fischer, Chimia 1991, 45, 77-80.

[2] http:/www.oci.unizh.ch/diversa/ siegfriedsymposiumindex.shtml or www.siegfried.ch

[3] http:/www.oci.unizh.ch/diversa/dch/2008 